\title{
PENGARUH PEMBERDAYAAN PEGAWAI TERHADAP KUALITAS PELAYANAN PUBLIK DI KANTOR KECAMATAN MEDAN TUNTUNGAN
}

\author{
Artha Lumban Tobing ${ }^{1}$ \\ Fakultas Ilmu Sosial dan Politik, Universitas HKBP Nommensen \\ arthatobing24@gmail.com
}

\begin{abstract}
ABSTRAK: Pelayanan publik merupakan salah satu produk aparatur pemerintah yang diberikan kepada masyarakat luas. Penyelenggaraan pelayanan publik merupakan salah satu fungsi utama dalam penyelenggaraan pemerintah yang menjadi kewajiban aparatur pemerintah. Profesionalisme merupakan faktor yang mempengaruhi kualitas pelayanan publik sehingga pegawai sebagai aparatur pemerintah harus bekerja secara profesional untuk memberikan pelayanan publik yang berkualitas. Penelitian ini adalah penelitian survey dengan pendekatan explanatory survey atau descriptive survey. yang bertujuan untuk menganalisi pengaruh profesionalisme terhadap kualitas pelayanan pada Kantor Kecamatan Medan Tuntungan. Dalam penelitian ini yang menjadi populasi adalah seluruh pegawai Kantor Kecamatan Medan Tuntungan yang berjumlah 47 orang. Mengingat jumlah populasi yang relative sedikit maka penentuan sampel dalam penelitian ini menggunakan metode total sampling, yakni mengambil seluruh populasi menjadi objek penelitian sebanyak 47 orang. Instrumen penelitian menggunakan kuesioner yang terdiri dari 30 item pertanyaan. Uji Hipotesis dalam penelitian ini dilakukan dengan analisis regresi linier sederhana dengan uji-t. Hasil penelitian memperlihatkan bahwa pemberdayaan profesionalisme pegawai memberi pengaruh signifikan terhadap kualitas pelayanan publik. Hal ini diindikasikan oleh nilai $t_{\text {-hitung }} \mathrm{X}(10.126)>\mathrm{t}_{\text {-tabel }}(1.98)$ dan sig-p $(0.001)<\mathrm{sig}-\square$ $(0.05)$, Besarnya pengaruh pemberdayaan profesionalisme pegawai terhadap kualitas pelayanan publik adalah sebesar $69.5 \%$.
\end{abstract}

Kata kunci : Pemberdayaan Profesionalisme Pegawai, Kualitas Pelayanan Publik

\begin{abstract}
Public service is one of the products of the government apparatus that is given to the wider community. The implementation of public services is one of the main functions in the administration of government which is the obligation of the government apparatus. Professionalism is a factor that affects the quality of public services so that employees as government officials must work professionally to provide quality public services.

This research is a survey research with an explanatory survey or descriptive survey approach. which aims to analyze the effect of professionalism on service quality at the Medan Tuntungan District Office. In this study, the population was all employees of the Medan Tuntungan District Office, amounting to 47 people. Given the relatively small number of populations, the determination of the sample in this study used the total sampling method, which took the entire population as the object of research as many as 47 people. The research instrument used a questionnaire consisting of 30 question items. Hypothesis testing in this study was carried out by simple linear regression analysis with t-test. The results of the study show that the empowerment of employee professionalism has a significant influence on the quality of public services. This is indicated by the value of $t$-count $X(10.126)>t$-table (1.98) and sig-p $(0.001)<$ sig- $\langle(0.05)$. The magnitude of the effect of empowering employee professionalism on the quality of public services is $69.5 \%$.
\end{abstract}

Keywords: empowerment of employee professionalism, quality of public services 


\section{PENDAHULUAN}

Pelayanan publik merupakan tugas utama yang hakiki dari aparatur pemerintah sebagai abdi negara dan abdi masyarakat. Pembukaan UUD 1945 alinea keempat secara tegas mengungkapkan 4 (empat) aspek pelayanan pokok aparatur terhadap masyarakat, yaitu melindungi segenap bangsa Indonesia dan seluruh tumpah darah Indonesia, memajukan kesejahteraan umum, mencerdaskan kehidupan bangsa dan melaksanakan ketertiban dunia berdasarkan kemerdekaan, perdamaian abadi dan keadilan sosial. Dalam Kepmenpan No. 81/93 dinyatakan bahwa pelayanan publik adalah segala bentuk pelayanan yang diberikan oleh pemerintah pusat/daerah, BUMN/ BUMD dalam rangka pemenuhan kebutuhan masyarakat, dan atau peraturan perundang-undangan yang berlaku. Kegiatan pelayanan publik pada dasarnya menyangkut pemenuhan suatu hal yang melekat pada setiap orang baik secara pribadi ataupun kelompok yang dilakukan secara universal. Pelayanan merupakan suatu tindakan untuk memenuhi kebutuhan orang lain (konsumen, pelanggan, tamu, klien, pasien, penumpang, dan lain-lain) yang tingkat pemuasannya dapat dirasakan oleh orang yang melayani maupun yang dilayani. Hal ini terjadi komunikasi batin antara kedua pihak dan kepuasan yang diperoleh tergantung pada situasi saat terjadinya interaksi pelayanan tersebut.

Penyelenggaraan pelayanan publik merupakan salah satu fungsi utama dalam penyelenggaraan pemerintah yang menjadi kewajiban aparatur pemerintah. Berdasarkan Keputusan Menteri Pendayagunaan Aparatur Negara Dan Reformasi Birokrasi No 15/tahun 2014 pada paragraph 1 butir c menyebutkan pengertian pelayanan publik adalah segala kegiatan pelayanan yang dilaksanakan oleh instansi pemerintah sebagai upaya pemenuhan kebutuhan orang, masyarakat, instansi pemerintah dan badan hukum maupun sebagai pelaksananan ketentuan peraturan perundang-undangan.

Standar pelayanan publik menurut SK Menpan No. 15 Tahun 2014 tentang Pedoman "Standar Pelayanan adalah tolok ukur yang dipergunakan sebagai pedoman penyelenggaraan pelayanan dan acuan penilaian kualitas pelayanan sebagai kewajiban dan janji Penyelenggara kepada masyarakat dalam rangka pelayanan yang berkualitas, cepat, mudah, terjangkau, dan terukur".

Rahmayanty, (2010. 85) mengatakan pentingnya pelayanan publik adalah untuk membantu, menyiapkan, mengurus, menyelesaikan keperluan maupun kebutuhan seseorang atau sekelompok orang. "Sedangkan pelayanan publik (asyarakat) secara umum dapat diartikan segala kegiatan pelayanan yang dilaksanakan oleh penyelenggara pelayanan public sebagai upaya pemenuhan kebutuhan penerima pelayanan maupun pelaksanaan ketentuan peraturan perundang-undangan".

Kenyataannya, profesionalisme pelayanan pemerintah di daerah masih belum maksimal, Untuk itu aparatur pemerintah sebagai abdi negara dan abdi masyarakat perlu diberdayakan dan dibina guna melaksanakan kegiatan dan kebijaksanaan yang dibuat oleh pemerintah sebagai bagian dari program pembangunan nasional. Pegawai yang profesional sangat diperlukan agar mampu meningkatkan mutu, pengetahuan, keterampilan karena didorong dengan banyaknya tanggung jawab tugas pemerintah serta pengabdiannya kepada masyarakat sesuai dengan kemampuan yang dimiliki pegawai. 
Demikian juga halnya dengan pegawai Kantor Kecamatan Medan Tuntungan, pelayanan publik belum maksimal misalnya dalam pengurusan Kartu Keluarga dan Akte Kelahiran, yang terkesan masih sangat lambat dan jauh dari memuaskan. Hal ini terjadi karena kurangnya profesionalisme petugas dalam memberikan pelayanan publik. Untuk itu, diperlukan pemberdayaan profesinalisme pegawai sehingga dapat memberikan pelayanan prima yang memuaskan masyarakat khususnya di wilayah Kecamatan Medan Tuntungan. Terlebih lagi, Kecamatan Medan Tuntungan adalah salah satu kecamatan terluas di kota Medan dengan jumlah penduduk yang relatif besar sehingga profesionalisme aparatur pemerintah yang bertugas di Kantor Kecamatan Medan Tuntungan sangat menentukan kualitas pelayananan.

Berdasarkan latar belakang masalah tersebut di atas, maka permasalahan penelitian dapat dirumuskan sebagai berikut : Bagaimana pengaruh pemberdayaan profesionalisme pegawai terhadap kualitas pelayanan publik di Kantor Kecamatan Medan Tuntungan. Tujuan umum penelitian adalah untuk mengetahui pengaruh pemberdayaan profesionalisme pegawai terhadap kualitas pelayanan publik di Kantor Kecamatan Medan Tuntungan.

Siagian Sondang, (2001. 163) menyatakan bahwa "profesionalisme adalah keandalan dalam pelaksanaan tugas, sehingga terlaksana dengan mutu tinggi, waktu yang tepat, cermat, dan dengan prosedur yang mudah dipahami dan diikuti oleh pelanggan". Terbentuknya aparatur profesional menurut pendapat tersebut memerlukan pengetahuan dan ketrampilan khusus yang dibentuk melalui pendidikan dan pelatihan sebagai instrument pemutakhiran. Pengetahuan dan keterampilan khusus yang dimiliki oleh aparat memungkinkannya untuk menjalankan tugas dan menyelenggarakan pelayanan publik dengan mutu tinggi, tepat waktu, dan prosedur yang sederhana. Kemampuan dan keahlian yang terbentuk juga harus diikuti dengan perubahan iklim dalam dunia birokrasi yang cenderung bersifat kaku dan tidak fleksibel.

Buchari Zainun, (2003 . 42), Pemberdayaan profesionalisme Pegawai Negeri Sipil adalah sesuai dengan prinsip pemanfaatan sumber daya manusia pegawai dimana "seluruh potensi apapun yang dimiliki pegawai diupayakan agar bermanfaat kepada semua pihak yang berkepentingan dengan pemanfaataan SDM pegawai itu. Tingkat kepuasan (satisfaksi) lebih penting dirasakan oleh pegawai sehingga mendorong pegawai untuk berprestasi makin tinggi sehingga semakin bermanfaat kepada organisasi tempatnya kerja dan pihak lain yang terkait dengan prestasi pegawai dan pelayanan organisasi kepada pihak-pihak tersebut".।

Konsep profesionalisme adalah mengembangkan konsep profesionalisme yang digunakan untuk mengukur bagaimana para profesionalis memandang profesi mereka yang tercermin dalam sikap dan perilaku mereka. Dalam hal ini dikemukakan bahwa ada hubungan timbal balik antara sikap dan perilaku yaitu perilaku profesionalisme merupakan cerminan dari sikap profesionalisme, demikian pula sebaliknya (Kalbers dan Fogarty, 1995, Rahmawati, 1997).

Pemberdayaan menurut Narayan (2002:14-15), adalah perluasan aset-asset dan kemampuan masyarakat yang tidak berdaya (miskin) menegoisasikan dengan mempengaruhi, mengontrol serta mengendalikan tanggung jawab lembagalembaga memengaruhi kehidupannya. Keberhasilan pemberdayaan sangat 
dipengaruhi oleh keinginan dan kehendak. Hal ini bukan hanya dapat mengontrol perbuatan-perbuatan atau kemampuan-kemampuan lain. Kehendak dapat memutuskan atau menentukan suatu kegiatan atau pekerjaan yang akan dilakukan, tetapi kehendak tidak dapat melaksanakan pekerjaan atau kegiatan. Kehendak hanyalah berlandaskan pada pemikiran kognitif (akal atau rasio), sedangkan tindakan berlandas pada pemikiran konatif (karsa) pada setiap manusia. Komponen utama pemberdayaan yang dimaksud disini adalah anggota organisasi, pemerintah dan masyarakat.

Salah satu pendekatan yang dapat digunakan dalam paradigma baru mengenai orientasi pelayanan para aparatur/ birokrat adalah pemberdayaan (empowerment). Pemberdayaan dalam hal ini dimaksudkan sebagai proses transformasi dari berbagai pihak yang mengarah pada saling menumbuhkembangkan, saling memperkuat, dan menambah nilai daya saing global yang saling menguntungkan. Tujuan pemberdayaan itu sendiri adalah untuk meningkatkan mutu, keterampilan, serta memupuk kegairahan dalam bekerja sehingga dapat menjamin terwujudnya kesempatan berpartisipasi dan melaksanakan pembangunan secara menyeluruh, dalam hal ini pemberdayaan terhadap aparatur pemerintah disesuaikan dengan ketentuan Undang-Undang No. 43 Tahun 1999 tentang Pokok-Pokok Kepegawaian.

Agung Kurniawan, ( 2005.5), Pemberdayaan profesionalisme aparatur Negara tentunya erat kaitannya dengan tiga fungsi utama yang harus dijalankan oleh pemerintah yakni "fungsi pelayanan masyarakat, fungsi pembangunan dan fungsi perlindungan. Hal terpenting adalah sejauhmana pemerintah dapat mengelola (memberdayakan) fungsi fungsi tersebut agar dapat menghasilkan pelayanan yagn ekonomis, efekif, efisien dan akuntabel kepada seluruh masyarakat".

Napitupulu Paimin, ( 2007. 78), Pentingnya pemberdayaan aparatur pemerintah adalah merupakan bagian dari "pertanggungjawaban kausal yang eksplisit terdiri dari empat unsur yaitu sumber daya (pemberdayaan), pengetahuan, pilihan dan maksud(purpose). Keempat unsure ini harus ada dalam mempertanggungjawabkan urusan publik".

Pelayanan menurut Kotler dalam Lukman adalah setiap kegiatan yang menguntungkan dalam suatu kumpulan atau kesatuan, dan menawarkan kepuasan meskipun hasilnya tidak terikat pada suatu produk secara fisik. Sampara berpendapat, pelayanan adalah suatu kegiatan atau urutan kegiatan yang terjadi dalam interaksi langsung antar seorang dengan orang lain dan menyediakan kepuasan kepada pelanggan.

Pelayanan publik adalah segala bentuk kegiatan pelayanan umum yang dilaksanakan oleh instansi pemerintah di pusat, di daerah, dan lingkungan Badan Usaha Milik Negara (BUMN) maupun Badan Usaha Milik Daerah (BUMD) dalam bentuk barang dan jasa, baik dalam rangka upaya pemenuhan kebutuhan masyarakat maupun dalam rangka pelaksanaan ketentuan peraturan perundangundangan. Ketiga komponen yang menangani sektor publik tersebut meyediakan pelayanan publik seperti kesehatan, pendidikan, keamanan dan ketertiban, bantuan sosial, dan penyiaran (Williamson, 1993). 
Sinambela, Poltak, (2010. 5), "Pelayanan publik diartikan sebagai pemberian layanan (melayani) keperluan orang atau masyarakat yang mempuyai kepentingan pada organisasi itu sesuai dengan aturan pokok dan tata cara yagn telah ditetapkan". Dengan demikian, pelayanan publik adalah pemnenuhan keinginan dan kebutuhan masayrakat oleh penyelenggara negara. Dengan demikian yang dimaksud dengan pelayanan publik adalah pelayanan yang di berikan oleh negara dan perusahaan milik negara kepada masyarakat untuk memenuhi kebutuhan dasarnya, dalam rangka menciptakan kesejahteraan masyarakat.

Waykof dalam Purnama N, 2006:19), menyebutkan kualitas layanan sebagai tingkat kesempurnaan yang diharapkan dan pengendalian atas kesempurnaan tersebut untuk memenuhi keinginan konsumen. Sedangkan menurut Parasuraman dalam Purnama kualitas layanan merupakan perbandingan antara layanan yang dirasakan (persepsi) konsumen dengan kualitas layanan yang diharapkan konsumen. Jika kualitas layanan yang dirasakan sama atau melebihi kualitas layanan yang diharapkan maka layanan dikatakan berkualitas dan memuaskan.

Begitu pula yang dikemukakan Tjiptono, bahwa pelayanan yang berhasil guna dalam suatu organisasi adalah bahwa pelayanan yang diberikan oleh anggota organisasi tersebut dapat memberikan kepuasan kepada konsumen atau pelanggannya. Sebagai tolak ukur adalah tidak adanya atau kurangnnya keluhan dari masyarakat /konsumen.

Konsep kualitas pelayanan dapat pula dipahami melalui "consumer behaviour" (perilaku konsumen) yaitu perilaku yang dimainkan oleh konsumen dalam mencari, membeli, menggunakan dan mengevaluasi suatu produk pelayanan yang diharapkan mampu memenuhi kebutuhannya. Keputusan keputusan konsumen untuk mengkonsumsi atau tidak mengkonsumsi suatu barang/ jasa dipengaruhi berbagai faktor, antara lain persepsinya terhadap kualitas pelayanan. Hal ini menunjukkan adanya interaksi yang kuat antara kepuasan konsumen dengan kualitas pelayanan

Selanjutnya Tjiptono (2011:174-175) menyatakan "ada 5 (lima) karakteristik yang digunakan untuk mengevaluasi kualitas pelayanan”, yaitu :

1. Reability (kehandalan), yakni kemampuan untuk menyampaikan layanan yang dijanjikan secara akurat sejak pertama kali.

2. Responsiveness (daya tanggap), berkenaan dengan kesediaan dan kemampuan penyediaan layanan untuk mebantu para pelanggan dan merespon permintaan mereka dengan segera.

3. Assurance (jaminan), berkenaan dengan pengetahuan dan kesopanan karyawan serta kemampuan mereka dalam menumbuhkan rasa percaya (trust) dan keyakinan pelanggan (confidence).

4. Empathy (empati), bahwa perusahaan memahami masalah para pelanggannya dan bertindak demi kepentingan pelanggan, serta memberikan perhatian personal kepada para pelanggan dan memiliki jam operasi yang nyaman. 
5. Tangibles (Bukti Fisik), berkenaan dengan penampilan fisik fasilitas layanan, peralatan/perlengkapan, sumber daya manusia, dan materi komunikasi perusahaan.

Sistem pelayanan publik yang baik akan menghasilkan kualitas pelayanan yang baik pula. Suatu sistem yang baik akan memberikan prosedur pelayanan yang terstandar dan memberikan mekanisme kontrol di dalam dirinya (built in control). Dengan demikian segala bentuk penyimpangan yang terjadi akan mudah diketahui. Sistem pelayanan harus sesuai dengan kebutuhan customers. Ini berarti organsiasi harus mampu merespons kebutuhan dan keinginan customers dengan menyediakan sistem pelayanan dan strategi yang tepat.

Kualitas pelayanan publik yang diberikan oleh jajaran aparatur birokrasi dipengaruhi oleh berbagai faktor, seperti tingkat kompetensi aparat, kualitas peralatan yang digunakan untuk memproses jenis pelayanan, budaya birokrasi, dan sebagainya. Kompetensi aparat birokrasi merupakan akumulasi dari sejumlah subvariabel seperti tingkat pendidikan, jumlah tahun pengalaman kerja, variasi pelatihan yang telah diterima. Sedangkan kualitas dan kuantitas peralatan yang digunakan akan mempengaruhi prosedur dan kecepatan output yang akan dihasilkan. Apabila organisasi menggunakan teknologi modern, seperti komputer, maka metode dan prosedur kerja akan berbeda dengan ketika organisasi menggunakan cara kerja manual.

Penelitian ini terdiri dari 1 (satu) variabel bebas yakni pemberdayaan dan pembinaan profesionalisme pegawai dan 1 (satu) variabel terikat yakni kualitas pelayanan publik sehingga kerangka konsep penelitian dapat digambarkan sebagai berikut :

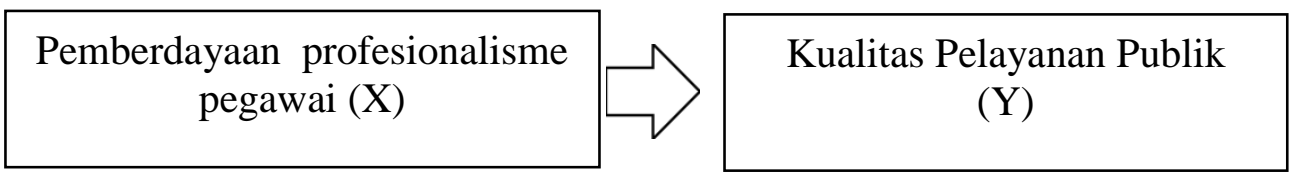

\section{Gambar 1. Kerangka Konsep Penelitian}

Hipotesis merupakan jawaban sementara terhadap rumusan masalah penelitian, oleh sebab itu rumusan masalah biasanya disusun dalam kalimat pertanyaan Berdasarkan teori dan kerangka berpikir maka penulis merumuskan hipotesis penelitian sebagai berikut : Apakah ada pengaruh pemberdayaan profesionalisme pegawai terhadap kualitas pelayanan publik pada Kantor Kecamatan Tuntungan.

\section{METODOLOGI PENELITIAN}

Jenis penelitian ini adalah penelitian survey dengan pendekatan explanatory survey atau descriptive survey. Nasir, (2003. 56), "Penelitian survey adalah penyelidikan yang diadakan untuk memperoleh fakta-fakta dari gejala-gejala yang ada dan mencari keterangan secara faktual, baik tentang institusi sosial, ekonomi atau politik dari suatu kelompok atau daerah". Penelitian dilakukan dalam waktu yang besamaan terhadap sejumlah individu atau unit, baik secara sensus atau dengan menggunakan sampel. Metode pendekatan explanatory survey tidak 
hanya melihat gambaran umum dari variabel atau hubungan antar variabel tetapi juga hubungan kausal atau pengaruh antar variabel dan sejauh mana pengaruhnya.

Lokasi penelitian ini dilakukan di Kanator Kecamatan Medan Tuntungan. Waktu penelitian adalah pada bulan November - Desember 2015.

Dalam penelitian ini yang menjadi populasi adalah seluruh pegawai Kantor Kecamatan Medan Tuntungan yang berjumlah 47 orang. Mengingat jumlah populasi yang relatif sedikit $(<100)$ maka penentuan sampel dalam penelitian ini menggunakan metode total sampling, yakni mengambil seluruh populasi menjadi objek penelitian sebanyak 47 orang

Kuesioner adalah instrumen penelitian berupa daftar pertanyaan secara tertulis yang disebarkan kepada sampel penelitian untuk mendapatkan data primer. Kuesioner dalam penelitian ini terdiri dari 30 item yakni 15 item tentang pemberdayaan profesionalisme pegawai dan 15 item tentang kualitas pelayanan publik.

Wawancara dilakukan terhadap pimpinan perusahaan terutama bidang keuangan untuk mendapatkan data sekunder untuk melengkapi data primer. Variabel penelitian ini terdiri dari variabel bebas $(\mathrm{X})$ dan variabel terikat $(\mathrm{Y})$ adalah sebagai berikut:

Tabel 1. Definisi Operasional dan Indikator Penelitian

\begin{tabular}{|l|l|l|l|l|}
\hline \multicolumn{1}{|c|}{ Variabel } & \multicolumn{1}{|c|}{$\begin{array}{c}\text { Definisi } \\
\text { Operasional }\end{array}$} & \multicolumn{1}{|c|}{ Indikator } & $\begin{array}{c}\text { Skala } \\
\text { Ukur }\end{array}$ & $\begin{array}{c}\text { Hasil } \\
\text { Ukur }\end{array}$ \\
\hline $\begin{array}{l}\text { Pemberdayaan } \\
\text { profesionalisme } \\
\text { pegawai (X) }\end{array}$ & $\begin{array}{l}\text { Yakni peningkatan } \\
\text { kemampuan dan } \\
\text { ketrampilan kerja } \\
\text { pegawai Kantor } \\
\text { Kecamatan Medan } \\
\text { Tuntungan }\end{array}$ & $\begin{array}{l}\text { 1). Pemberdayaan } \\
\text { 2) Pembinaan }\end{array}$ & Likert & Ordinal \\
\hline $\begin{array}{l}\text { Kualitas } \\
\text { pelayanan } \\
\text { publik (Y) }\end{array}$ & $\begin{array}{l}\text { Yakni citra } \\
\text { pelayanan yang } \\
\text { diberikan pegawai } \\
\text { Kantor Kecamatan } \\
\text { Medan Tuntungan } \\
\text { kepada masyarakat }\end{array}$ & $\begin{array}{l}\text { 1) Bukti langsung } \\
\text { 2) Kehandalan } \\
\text { 4) Saminan }\end{array}$ & Limpati & Ordinal \\
\hline
\end{tabular}

Analisa data adalah proses penyederhanaan data ke dalam bentuk yang lebih mudah dibaca dan dipresentasikan. Untuk menganalisis data pada penelitian ini peneliti menggunakan uji kualitas data yang terdiri dari 1) Uji validitas dan 2) Uji reliabilitas.

Validitas atau kesahihan merupakan kemampuan suatu instrumen (alat pengukur) mengukur apa yang harus diukur. Untuk mendapatkan data yang valid dalam metode kuantitatif diperlukan instrumen yang valid, oleh karenanya diperlukan uji validitas instrument. Validitas instrument menggambarkan tingkat instrument yang mampu mengukur apa yang akan diukur. Ada dua jenis validitas 
instrument penelitian yaitu: validitas logis dan validitas empiris. Maksud dari validitas logis apabila instrumen tersebut secara analisis akal sudah sesuai dengan isi dan aspek yang diungkapkan.

Situmorang, Helmi (2007. 37), "Reliabilitas adalah indeks yang menunjukkan sejauhmana suatu alat pengukur dapat dipercaya atau dapat diandalkan. Bila suatu alat pengukur dipakai dua kali untuk mengukur gejala yang sama dan hasil pengukuran yang diperoleh relatif konsisten, maka alat pengukur tersebut adalah reliabel". Menurut Santoso reliabilitas suatu tes adalah seberapa besar derajat tes mengukur secara konsisten sasaran yang diukur. Reliabilitas dinyatakan dalam bentuk angka, biasanya sebagai koefisien. Koefisien tinggi berarti reliabilitas tinggi.

Uji Hipotesis dalam penelitian ini dilakukan dengan analisis regresi linier sederhana dengan uji-t karena penelitian ini hanya ada 1 (satu) variabel bebas dan 1(satu) variabel terikat. Menurut Sudjana :"dengan menggunakan derajat kebebasan $(\mathrm{db}=\mathrm{N}-2)$ pada daftar signifikansi 5\%, maka apabila $\mathrm{t}_{\text {-hitung }}>\mathrm{t}_{\text {-tabel }}$ dinyatakan kontribusi yang dihitung berarti atau signifikan.

Koefisien Determinasi $\mathrm{R}^{2}$ bertujuan untuk mengukur seberapa besar pengaruh variabel independen memengaruhi perubahan yang terjadi pada variabel dependen. Jika $\mathrm{R}^{2}$ yang diperoleh dari hasil perhitungan mendekati 1 (satu) atau 0 $\leq \mathrm{R}^{2} \leq 1$, maka semakin kuat pengaruh variabel bebas terhadap variabel terikat. Sebaliknya apabila nilai $\mathrm{R}^{2}$ mendekati nol, maka semakin lemah pengaruh variabel bebas terhadap variabel terikat.

\section{HASIL PENELITIAN}

Umur responden dari 47 responden, 3 orang $(6.4 \%)$ berumur dibawah 30 tahun, 13 orang $(27.7 \%)$ berumur antara 30-40 tahun, 29 orang $(61.7 \%)$ berumur antara 41-50 tahun dan 2 orang (4.3\%) berumur di atas 50 tahun. Dengan demikian, mayoritas responden berumur antara 41-50 tahun yakni sebanyak 29 orang $(61.7 \%)$. Sementara Pendidikan dikelompokkan kedalam 3 kategori yakni D3, S1 dan S2. Dari 47 responden, 9 orang (19.1\%) berpendidikan D3, 35 orang $(74.5 \%)$ berpendidikan S1 dan 3 orang $(6.4 \%)$ berpendidikan S2. Dengan demikian, mayoritas responden memiliki pendidikan $S 1$ yakni sebanyak 35 orang $(74.5 \%)$.

Hasil uji validitas terhadap ke-30 item pernyataan penelitian dapat dirangkum pada tabel berikut :

Tabel 2. Hasil Uji Validitas

\begin{tabular}{|l|c|c|c|}
\hline $\begin{array}{c}\text { Item } \\
\text { pernyataan }\end{array}$ & $\begin{array}{c}\text { r-hitung } \\
\text { validitas }\end{array}$ & r-tabel & Kesimpulan \\
\hline \multicolumn{4}{|c|}{ Pemberdayaan profesionalisme pegawai (X) } \\
\hline Daya1 & .509 & 0.36 & Valid \\
\hline Daya2 & .638 & 0.36 & Valid \\
\hline Daya3 & .627 & 0.36 & Valid \\
\hline Daya4 & .615 & 0.36 & Valid \\
\hline Daya5 & .570 & 0.36 & Valid \\
\hline
\end{tabular}




\begin{tabular}{|l|c|c|c|}
\hline Daya6 & .578 & 0.36 & Valid \\
\hline Daya7 & .607 & 0.36 & Valid \\
\hline Daya8 & .524 & 0.36 & Valid \\
\hline Daya9 & .570 & 0.36 & Valid \\
\hline Daya10 & .618 & 0.36 & Valid \\
\hline Daya11 & .484 & 0.36 & Valid \\
\hline Daya12 & .638 & 0.36 & Valid \\
\hline Daya13 & .627 & 0.36 & Valid \\
\hline Daya14 & .615 & 0.36 & Valid \\
\hline Daya15 & .570 & 0.36 & Valid \\
\hline Kualitas pelayanan publik (Y) & & \\
\hline Kuali1 & .548 & 0.36 & Valid \\
\hline Kuali2 & .611 & 0.36 & Valid \\
\hline Kuali3 & .618 & 0.36 & Valid \\
\hline Kuali4 & .614 & 0.36 & Valid \\
\hline Kuali5 & .585 & 0.36 & Valid \\
\hline Kuali6 & .592 & 0.36 & Valid \\
\hline Kuali7 & .596 & 0.36 & Valid \\
\hline Kuali8 & .519 & 0.36 & Valid \\
\hline Kuali9 & .585 & 0.36 & Valid \\
\hline Kuali10 & .631 & 0.36 & Valid \\
\hline Kuali11 & .478 & 0.36 & Valid \\
\hline Kuali12 & .628 & 0.36 & Valid \\
\hline Kuali13 & .618 & 0.36 & Valid \\
\hline Kuali14 & .614 & 0.36 & Valid \\
\hline Kuali15 & .513 & 0.36 & Valid \\
\hline
\end{tabular}

Tabel 2 memperlihatkan bahwa nilai $\mathrm{r}_{\text {-hitung }}$ validitas ke-30 item pernyataan adalah lebih besar dari $\mathrm{r}_{\text {-tabel }}$ (0.36) sehingga dapat disimpulkan bahwa ke-30 item pernyataan adalah valid.

Uji reliabilitas terhadap kedua variabel penelitian memperlihatkan hasil sebagai berikut :

Tabel 3. Hasil Uji Reliabilitas

\begin{tabular}{|c|l|c|c|c|}
\hline No & \multicolumn{1}{|c|}{ Variabel } & $\begin{array}{c}\text { r-hitung } \\
\text { reliabilitas }\end{array}$ & r-tabel & Kesimpulan \\
\hline 1 & $\begin{array}{l}\text { Pemberdayaan } \\
\text { profesionalisme } \\
\text { Kualitas pelayanan } \\
\text { publik }\end{array}$ & 0.900 & 0.6 & Reliabel \\
\hline
\end{tabular}

Sumber : Hasil penelitian 2015 (data diolah) 
Tabel 3 memperlihatkan bahwa kedua variabel penelitian memiliki nilai rhitung reliabilitas lebih besar dari 0.6, sehingga dapat disimpulkan bahwa kedua variabel penelitian adalah reliabel.

Uji korelasi yang dilakukan dengan uji korelasi Pearson memperlihatkan hasil sebagai berikut :

Tabel 4. Hasil Uji Korelasi

\begin{tabular}{|ll|r|r|}
\hline \multicolumn{1}{|c|}{ Correlations } \\
\hline & $\begin{array}{c}\text { Pemberd } \\
\text { ayaan } \\
\text { Profesion } \\
\text { alisme }\end{array}$ & $\begin{array}{c}\text { Kualitas } \\
\text { Pelayanan }\end{array}$ \\
\hline Pemberdayaan & Pearson Correlation & 1 & $.834^{\star *}$ \\
Profesionalisme & Sig. (2-tailed) & 47 & .000 \\
& $\mathrm{~N}$ & $.834^{* *}$ & 47 \\
\hline Kualitas Pelayanan & Pearson Correlation & .000 & 1 \\
& Sig. (2-tailed) & 47 & 47 \\
\hline & $\mathrm{N}$ & \\
\hline \multirow{2}{***}{. Correlation is significant at the 0.01 level (2-tailed). }
\end{tabular}

Hasil uji korelasi memperlihatkan bahwa nilai koefisien korelasi adalah sebesar 0.834 dengan nilai signifikansi $=0.001$, sehingga dapat disimpulkan bahwa ada korelasi signifikan antara pemberdayaan profesionalisme pegawai dengan kualitas pelayanan publik.

Untuk mengetahui besarnya pengaruh variabel bebas $\mathrm{X}$ (pemberdayaan profesionalisme pegawai) terhadap variabel terikat Y (kualitas pelayanan publik), dilakukan uji determinasi $\mathrm{R}$ dengan hasil sebagai berikut :

Tabel 5. Hasil Uji Determinasi $R$

Model Summary ${ }^{b}$

\begin{tabular}{|l|r|r|r|r|}
\hline Model & \multicolumn{1}{|c|}{ R } & R Square & $\begin{array}{c}\text { Adjusted } \\
\text { R Square }\end{array}$ & $\begin{array}{c}\text { Std. Error of } \\
\text { the Estimate }\end{array}$ \\
\hline 1 & $.834^{\mathrm{a}}$ & .695 & .688 & 1.24767 \\
\hline
\end{tabular}

a. Predictors: (Constant), Pemberdayaan dan Pembinaan Profesionalisme

b. Dependent Variable: Kualitas Pelayanan

Tabel 5 memperlihatkan bahwa nilai $\mathrm{r}_{\text {square }}=0.695$, hal ini berarti sebesar $69.5 \%$ kualitas pelayanan publik dapat diasumsikan oleh pemberdayaan profesionalisme pegawai sedangkan selebihnya sebesar $30.5 \%$ diasumsikan oleh faktor-faktor lain diluar penelitian.

Mengingat penelitian ini hanya terdiri dari 1 (satu) variabel bebas) yakni pemberdayaan profesionalisme pegawai, maka uji hipotesis dilakukan dengan menggunakan uji regresi linier sederhana secara parsial yakni dengan uji-t dengan hasil sebagai berikut: 
Tabel 6. Hasil Uji Pengaruh Pemberdayaan Profesionalisme Pegawai Terhadap Kualitas Pelayanan Publik

Coefficients ${ }^{a}$

\begin{tabular}{|c|c|c|c|c|c|c|}
\hline \multirow{2}{*}{\multicolumn{2}{|c|}{ Model }} & \multicolumn{2}{|c|}{$\begin{array}{l}\text { Unstandardized } \\
\text { Coefficients }\end{array}$} & \multirow{2}{*}{$\begin{array}{c}\text { Standardized } \\
\text { Coefficients } \\
\text { Beta }\end{array}$} & \multirow[b]{2}{*}{$t$} & \multirow[b]{2}{*}{ Sig. } \\
\hline & & B & Std. Error & & & \\
\hline \multirow[t]{2}{*}{1} & (Constant) & 24.451 & 2.735 & & 8.940 & .000 \\
\hline & $\begin{array}{l}\text { Pemberdayaan } \\
\text { Profesionalisme }\end{array}$ & .552 & .055 & .834 & 10.126 & .000 \\
\hline
\end{tabular}

a. Dependent Variable: Kualitas Pelayanan

Tabel 6 memperlihatkan bahwa nilai $t_{\text {-hitung }}$ pemberdayaan profesionalisme pegawai $=10.126$ dengan nilai sig-p $=0.001$. Jika dibandingkan dengan nilai $\mathrm{t}-$ tabel (1.98) dan sig- $\alpha$ (0.05), terbukti bahwa $t_{\text {-hitung }} \mathrm{X}(10.126)>\mathrm{t}_{\text {-tabel }}$ (1.98) dan sig-p $(0.001)<\operatorname{sig}-\alpha \quad(0.05)$, sehingga hasil uji-t ini memenuhi persyaratan hipotesis yakni jika sig-p $<0.05$, maka Ha diterima yakni ada pengaruh signifikan variabel bebas terhadap variabel terikat). Dengan demikian dapat disimpulkan bahwa pemberdayaan profesionalisme pegawai (X) berpengaruh signifikan terhadap variabel terikat (kualitas pelayanan publik).

Persamaan regresi dapat disusun sesuai dengan nilai koefisien hasil perhitungan berikut :

$$
\begin{aligned}
& Y=a+b X \\
& Y=24.451+0.552 X
\end{aligned}
$$

Bentuk persamaan ini berarti bahwa jika faktor lain dianggap tetap, maka setiap perbaikan pemberdayaan profesionalisme pegawai sebesar 1 point, akan dapat meningkatkan kualitas pelayanan publik sebesar $24.451+0.552$ point $=$ 25.003 point.

\section{PEMBAHASAN}

Hasil analisis deskriptif memperlihatkan bahwa mayoritas responden menyatakan bahwa pemberdayaan profesionalisme pegawai Kantor Camat Medan Tuntungan adalah baik $(51.1 \%)$ dan mayoritas responden menyatakan bahwa kualitas pelayanan publik Kantor Camat Medan Tuntungan adalah baik (59.6\%). Hal ini berarti ada hubungan linier antara pemberdayaan profesionalisme pegawai dengan kualitas pelayanan publik. Dengan kata lain, semakin baik pemberdayaan profesionalisme pegawai semakin tinggi pula kualitas pelayanan publik perusahaan. Hal ini juga dikonfirmasi oleh hasil analisis regresi dimana pemberdayaan profesionalisme pegawai memberi pengaruh signifikan terhadap kualitas pelayanan publik.

Ditinjau dari bukti langsung sebagai salah satu dari indikator kualitas pelayanan, hasil penelitian dan pengamatan di lapangan memperlihatkan bahwa bukti langsung yang diperlihatkan oleh Kantor Camat Medan Tuntungan terhadap masyarakat adalah adanya fasilitas penunjang kerja pelayanan seperti perangkat komputer yang sudah memiliki database sehingga semakin memudahkan kerja pelayanan dalam memenuhi kebutuhan masyarakat seperti pengurusan Kartu Kelurahan, KTP, dan dokumen penting lainnya. Bukti langsung kualitas pelayanan lainnya yang nyata terlihat pada Kantor Camat Medan Tuntungan 
adalah ketersediaan kartu pelayanan setiap kali masyarakat berurusan sehingga semuanya tertib menunggu sesuai dengan urutan nomor dalam kartu pelayanan.

Ditinjau dari kehandalan, hasil pengamatan di lapangan pada Kantor Kecamatan Medan Tuntungan memperlihatkan bahwa pegawai Kantor Kecamatan Medan Tuntungan belum memiliki kemampuan merata dalam menyediakan pelayanan yang memuaskan. Masih ada beberapa pegawai yang terkesan lamban dalam memberikan pelayanan ketika ada anggota masyarakat yang berurusan baik dalam hal urusan KTP, kartu keluarga, surat mandah dan kepentingan lainnya sehingga membuat masyarakat kurang puas. Ditinjau dari ketanggapan, hasil pengamatan di lapangan memperlihatkan bahwa pada umumnya pegawai Kantor Kecamatan Medan Tuntungan memiliki keinginan untuk membantu masyarakat dalam memenuhi keperluannya secara cepat dan tepat, namun masih ada pegawai yang kurang tanggap terhadap kepentingan anggota masyarakat misalnya bidang pendaftaran administrasi yang sering mengulur-ulur waktu sehingga menimbulkan antrian panjang.

Ditinjau dari aspek jaminan (assurance) yang mencakup kemampuan, keramahan, dan kesopanan, hasil pengamatan di lapangan memperlihatkan bahwa pada umumnya pegawai Kantor Kecamatan Medan Tuntungan memiliki sikap ramah dan santun dalam meyalani masyarakat yang datang, tetapi karakter ramah tersebut hanya terlihat disaat anggota masyarakat belum banyak yang datang. Berbeda dengan jika anggota masyarakat mulai antrian, sikap keramahan tersebut berubah menjadi agak emosional. Hal ini tentunya membuat anggota masyarakat menjadi kurang nyaman berurusan.

Ditinjau dari sikap empati, yakni sikap tegas dan peduli terhadap anggota masyarakat, hasil pengamatan di lapangan memperlihatkan bahwa pada umumnya pegawai Kantor Kecamatan Medan Tuntungan cukup peduli dengan kepentingan anggota masyarakat, hanya saja masih ada sikap diskriminatif saat antrian sehingga yang baru datang terkadang dilayani lebih dulu dari mereka yang sudah lama antrian. Hal ini tentunya menimbulkan ketidakpuasan anggota masyarakat sehingga banyak yang komplain, bahkan sebagian pulang untuk kemudian mengurung niatnya untuk mengurus kepentingannya.

Penelitian ini sejalan dengan penelitian Martha Magda, 2012, Program Studi Ilmu Pemerintahan Kerjasama Fakultas Ilmu Sosial dan Ilmu Politik Universitas Tanjungpura dengan Pemerintah Provinsi Kalimantan Barat dengan judul Pengaruh Profesionalisme Kerja Aparatur Terhadap Kualitas Pelayanan Publik Di Dinas Pendidikan Kabupaten Ketapang dan membuktikan bahwa profesionalisme memberi pengaruh signifikan terhadap kualitas pelayanan $(\mathrm{p}<0.05)$.

Penelitian ini sejalan dengan penelitian Jenilda Paputungan, dengan judul Pemberdayaan Aparat Kelurahan Dalam Meningkatkan Kualitas Pelayanan Publik (Suatu Studi Di Kecamatan Singkil Kota Manado) dan dengan menggunakan analisis regresi sederhana bahwa pemberdayaan aparat kelurahan terbukti memberi pengaruh terhadap peningkatan kualitas pelayanan publik. Penelitian ini sejalan dengan penelitian Arfhi Ajudia, 2013 Program Studi Ilmu Pemerintahan Kerjasama Fakultas Ilmu Sosial dan Ilmu Politik Universitas Tanjungpura dengan Pemerintah Provinsi Kalimantan Barat dengan judul Pengaruh Pemberdayaan Pegawai Terhadap Kualitas Pelayanan Publik Di Kantor 
Pelayanan Wilayah Utama Perusahaan Daerah Air Minum (Pdam) Tirta Khatulistiwa Pontianak dan hasil penelitian membuktikan bahwa bahwa pemberdayaan aparat kelurahan terbukti memberi pengaruh terhadap peningkatan kualitas pelayanan public

Penelitian ini juga sejalan dengan penelitan Andita Mandasari, 2011, dengan judul Pengaruh Profesionalisme Pegawai Terhadap Kualitas Pelayanan Publik Pada Kantor Dinas Kependudukan Dan Catatan Sipil Kabupaten Kutai Barat dan hasil penelitian membuktikan bahwa professional memberi pengaruh signifikan terhadap kualitas pelayanan $(\mathrm{p}<0.05)$.

Dalam penyelenggaraan pelayanan publik, aparatur pemerintah bertanggung jawab untuk memberikan pelayanan yang terbaik kepada masyarakat dalam rangka menciptakan kesejahteraan masyarakat. Masyarakat berhak untuk mendapatkan pelayanan yang terbaik dari pemerintah karena masyarakat telah memberikan dananya dalam bentuk pembayaran pajak, retribusi dan berbagai pungutan lainnya. Salah satu tugas pokok pemerintah yang terpenting adalah memberikan pelayanan kepada masyarakat, karena itu organisasi pemerintah sering disebut sebagai 'pelayan masyarakat' (publik servant).

Hal ini sejalan dengan pendapat Surjono (2000) bahwa pemerintah tidaklah diadakan untuk melayani dirinya sendiri, tetapi untuk melayani masyarakat serta menciptakan kondisi yang memungkinkan setiap anggota masyaraakat mengembangkan kemampuan dan kreativitasnya demi mencapai tujuan bersama. Oleh karena itu, birokrasi publik (pemerintah) berkewajiban dan bertanggung jawab untuk memberikan layanan terbaik dan profesional kepada masyarakat. Hasil penelitian ini secara teoretis sejalan dengan pendapat beberapa ahli, diantaranya, Said (2003) mengatakan bahwa "Sedini mungkin pemerintah mengusahakan profesionalisme aparaturnya dan sedapat mungkin juga meningkatkan profesionalitasnya. Walaupun harus diakui, bahwa profesionalisme aparatur bukan satu-satunya jalan untuk meningkatkan pelayanan publik, karena masih ada alternatif lain, misalnya dengan menciptakan sistem dan prosedur kerja yang efisien tetapi tuntutan adanya aparatur yang profesional tidak dapat dihindari oleh pemerintah yang bertanggung jawab. Untuk meningkatkan profesionalisme aparatur kelurahan, maka diperlukan upya-upaya pemberdayaan aparatur itu sendiri, baik melalui pembinaan, pendidikan dan pelatihan, pemberian fasilitas dan peralatan kerja serta pemberian aksesibilitas yang memadai sehingga pada gilirannya akan mendorong peningkatan kualitas pelayanan kepada masyarakat.

Sehubungan dengan peningkatan kualitas pelayanan publik, maka upaya pemberdayaan aparat dimaksudkan untuk meningkatkan kemampuan/ keterampilan atau skill aparat pemerintah kelurahan maupun kecamatan khususnya mereka yang bertugas melakukan pelayanan publik. Dengan demikian dapat disimpulkan bahwa semakin tinggi tingkat profesionalisme pegawai, khususnya aparatur kecamatan, diperoleh melalui proses pemberdayaan, akan semakin baik dan meningkat pula kualitas layanan yang diberikan kepada masyarakat pengguna jasa (publik), 


\section{KESIMPULAN}

Berdasarkan hasil analisis pemberdayaan dan pembinaan profesionalisme pegawai terhadap kualitas pelayanan publik Kantor Camat Medan Tuntungan , dapat disimpulkan bahwa ;

1. Pemberdayaan profesionalisme pegawai Kantor Camat Medan Tuntungan pada umumnya sudah berlangsung baik. Hal ini diindikasikan oleh mayoritas responden yang menjawab bahwa pemberdayaan dan pembinaan profesionalisme pegawai adalah baik.

2. Kualitas pelayanan publik Kantor Camat Medan Tuntungan pada umumnya meningkat sesuai dengan pemberdayaan profesionalisme pegawai .Hal ini diindikasikan oleh mayoritas responden yang menjawab bahwa kualitas pelayanan publik perusahaan tercapai dengan baik.

3. Besarnya determinasi (faktor penentu) pemberdayaan profesionalisme pegawai terhadap kualitas pelayanan publik adalah sebesar 69.5\%, selebihnya sebesar $30.5 \%$ ditentukan oleh faktor-faktor lain yang tidak diteliti.

4. Pemberdayaan profesionalisme pegawai memberi pengaruh signifikan terhadap kualitas pelayanan publik. Hal ini diindikasikan oleh nilai $\mathrm{t}_{\text {-hitung }} \mathrm{X}$ $(10.126)>t_{\text {tabel }}(1.98)$ dan sig-p $(0.001)<\operatorname{sig}-\alpha(0.05)$,

Kepada Kantor Camat Medan Tuntungan, disarankan untuk lebih memperhatikan pemberdayaan profesionalisme pegawai sehingga dapat memberikan dampak positif yang lebih besar terhadap kualitas pelayanan publik.

\section{DAFTAR PUSTAKA}

Kasmadi, Nia Siti Nuraidah, 2014 Panduan Modern Penelitian Kuantitatif. Bacaan Wajib Bagi Peneliti, Guru dan Mahasiswa Program S1, dan S2 di Lingkungan Pendidikan.Bandung: Alfabeta

Kurniawan, Agung, 2005, Transformasi Pelayanan Publik. Yogyakarta: Pembaharuan

Nasir Muhammad, 2003, Metode Penelitian, Jakarta Ghalia Indonesia cetakan kelima.

Napitupulu Paimin, 2007, Pelayanan Publik dan Customer Satisfaction, Prinsip Prinsip Dasar Agar Pelayanan Publik Lebih Berorientasi Pada Kepuasan dan Kepentingan Masyarakat. Bandung: Alumni.

Siagian, Sondang, 2000, Administrasi Pembangunan. Jakarta: Bumi Aksara

Sinambela, Poltak, 2006, Reformasi Pelayanan Publik, Teori, Kebijakan dan Implementasi. Jakarta :Bumi Aksara

Situmorang, Helmi, Analisis Data Penelitian, Menggunakan Program SPSS Medan: USU Press, 2008 
Tjiptono, Fandi, 2008, Service Management, Mewujudkan Layanan Prima. Yogyakarta: Andi

Rahmayanty, Nina, 2010 Manajemen Pelayanan Prima, Mencegah Pembelotan dan Membangun Customer Loyality. ,Jakarta: Graha Ilmu.

Zainun, Buchari, 2004 Administrasi dan Manajemen Sumber Daya Manusia Pemerintah Negara Indonesia. ,Jakarta: Ghalia Indonesia

Keputusan Menteri Pendayagunaan Aparatur Negara Nomor 63 Tahun 2003 Tentang Pedoman Umum Penyelenggaraan Pelayanan Publik

Peraturan Menteri Negara Pendayagunaan Aparatur Negara (MenPan) Nomor 15 Tahun 2014 Bab II. 